\title{
The Effect of Extreme Climatic Events on Extreme Runoff in the Past 50 Years in the Manas River Basin, Xinjiang, China
}

\author{
Xiangling Tang ${ }^{*}$, Xin Lv² \\ ${ }^{1}$ Geography Department of Natural Science of Shihezi University, Shihezi, China \\ ${ }^{2}$ Production and Construction Corps in Xinjiang Key Laboratory of Oasis Ecological Agriculture, Shihezi, China \\ Email: *txl_tea@126.com
}

Received 21 July 2015; accepted 6 March 2016; published 10 March 2016

Copyright (C) 2016 by authors and Scientific Research Publishing Inc.

This work is licensed under the Creative Commons Attribution International License (CC BY).

http://creativecommons.org/licenses/by/4.0/

(c) (i) Open Access

\section{Abstract}

To analyze extreme climatic change features and effects on runoff in the Manas River basin, Xinjiang, data were collected including daily mean temperature, daily highest and lowest temperatures, and daily precipitation from six meteorological stations in the Manas River basin as well as daily runoff data from the Kensiwate hydrologic stations during 1960-2010. By adopting the threshold value of extreme climatic events defined by ET ALDDMI and with the aid of nonparametric statistical tests, Pearson III methods, and others, the effect of extreme climatic events on extreme runoff in the past 50 years in the Manas River basin, Xinjiang, was analyzed. The results showed that in the past 50 years, 1) extreme warming events (annual extreme maximum temperature, warm-day and warm-night index) have risen significantly $(P<0.05)$. Among these the warm-day and warm-night indices decreased abruptly in 2001 and 1996, respectively. With respect to extreme cold events (annual extreme minimum temperature, cold-day and cold-night indices), the extreme minimum temperature was high after 1976, and the cold-day index weakened significantly, similar to the cold-night index. 2) Except for the continuous drought days (CDD), the other five indices of extreme precipitation events appeared to trend upward, with an abrupt change around 1993. 3) Flood events in 1990, mostly in summer, accounted for $42.9 \%$ of the total number of floods since 1960. Floods increased mainly because extremely high summer temperatures increased snowmelt, increasing inflow to the rivers, which combined with more precipitation to cause the increase in summer peak flood discharge.

\section{Keywords}

Manas River Basin, Extreme Climate Events, Extreme Runoff, Influence

\footnotetext{
${ }^{*}$ Corresponding author.

How to cite this paper: Tang, X.L. and Lv, X. (2016) The Effect of Extreme Climatic Events on Extreme Runoff in the Past 50 Years in the Manas River Basin, Xinjiang, China. American Journal of Climate Change, 5, 15-26. 


\section{Introduction}

Many studies have demonstrated that extreme climatic events, such as floods, droughts, typhoons, high temperatures, low temperatures, rain, snow, freezes, and so on, seriously affect social stability, economic development, and national well-being [1]. Climatic change is likely to alter the current global hydrologic cycle, resulting in increasing frequency and strength of extreme climatic events [2], presenting a serious threat to global and regional water security and a significant challenge to the survival of mankind and sustainable social development [3]. These influences, however, are different in both space and time due to spatial and temporal variations of temperature changes [4] [5]. Therefore, assessing long-term characteristics of variations of extreme climate events, especially extreme climatic events on Extreme Runoff is essential to evaluate climatic hazards and to contribute to development of drought and flood mitigation strategies such as supplementary irrigation, flood control structures, etc. [6].

For the past few years, extreme hydrologic events, occurring against the background of extreme climate changes, have spurred attention by many scholars worldwide, becoming a top issue in climatic and hydrologic research. Kunkel et al. [7]-[11] studied extreme precipitation and temperature variations in America, Canada, Mexico, Australia, Norway, Poland, and Russia.

Zhai et al. [12]-[15] analyzed extreme precipitation events in China, east China, south China, and the Yangtze River basin. Yang [16] and Zhang et al. [17] analyzed temporal and spatial variation, including interannual variation in precipitation events. Cheng et al. [18] analyzed runoff and climatic change as well as abrupt variations in the Tarim River basin, and Tang et al. [19] analyzed climatic change in the Manas River basin and its effect on runoff. However, but few recent studies have addressed the possible effects of extreme climatic events on the Manas River basin.

The Manas River basin is located on the south edge of the Junggar basin, Xinjiang. Its hills, oases, and desert ecosystems make it an interesting ecological region. The influence of snowmelt is very weak in the Manas River basin due to the combined effects of climatic change and human activities. Temperature rise causes seasonal variation in snowmelt runoff, resulting in variation in water resources, which in turn decreases the stability and renewability of the hydrologic cycle and increases uncertainty regarding the frequency and strength of extreme future climatic and hydrological events. Therefore, study of extreme climatic events and impact on extreme runoff will be very significant for mitigating disasters and damages and promoting regional water security.

\section{Material and Methods}

\subsection{General Information of the Research Zone}

Manas River basin locates at the joint of northern foot of Tianshan Mountain and south brim of Junggar Basin. Its south starts from northern foot divide of Eren Habirga Range, and neighbors Hejing County, and its north ends to Gurbantunggut Desert, its east starts from Taxi River, and west ends to Bayingou River. The geographical location is $43^{\circ} 27^{\prime} \mathrm{N}-45^{\circ} 21^{\prime} \mathrm{N}, 85^{\circ} 01^{\prime} \mathrm{E}-86^{\circ} 32^{\prime} \mathrm{E}$. The longest length from east to west is $198.7 \mathrm{~km}$, and the widest width from south to north is $260.8 \mathrm{~km}$. The total area is $2.43 \times 10^{4} \mathrm{~km}^{2}$, and among it, there are $1.1 \times 10^{4}$ $\mathrm{km}^{2}$ mountain area, $9.6 \times 10^{4} \mathrm{~km}^{2}$ plain and $3.5 \times 10^{4} \mathrm{~km}^{2}$ sand dune. The landscape within basin tilts from southeast to northeast. The highest height above sea level is $5242.5 \mathrm{~m}$, while the lowest is $256 \mathrm{~m}$. The mountain whose height is above $3600 \mathrm{~m}$ is covered with accumulated snow all year long. The glacier's area is 1037.68 $\mathrm{km}^{2}$, and the allocation is showed as Figure 1.

\subsection{Data and Methods}

The study was based on meteorological data from 6 stations and analysis of indices generated by RClimDex (http://cccma.seos.uvic.ca/ETCCDI/software.shtml). The data of daily precipitation, maximum temperature and minimum temperature were provided by the China Meteorological Administration in Xinjiang Uygur Autonomous Region. The 6 selected stations all have data available for at least 52 years. Although most have longer records, only the period from January 1, 1960 to December 31, 2012 was analyzed, because six stations began recording in 1959. Detailed information about the stations, which are located at altitudes between $337.8 \mathrm{~m}$ and $523.2 \mathrm{~m}$, is shown in Table 1.

Data quality control is a necessary step before analysis of variations of temperature and precipitation because erroneous outliers can seriously influence trends. In this study, data quality control was performed by using the 


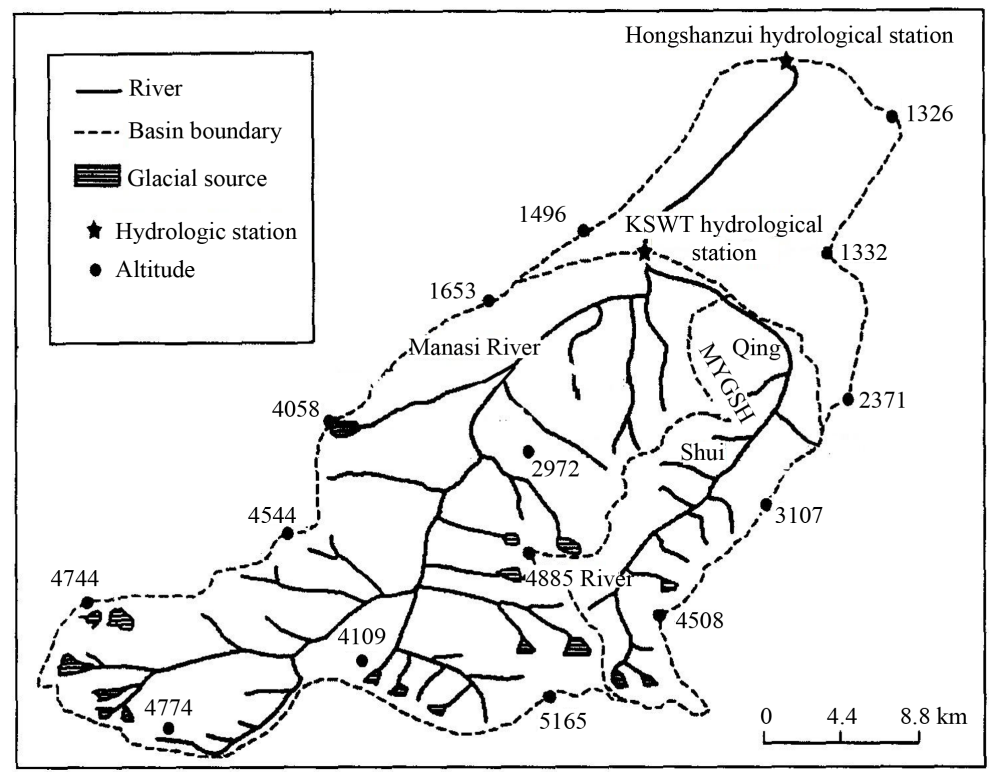

Figure 1. The figure of Manas River water system of Manas River basin (in accordance with YUAN Yujiang, YU Shulong, 2005).

Table 1. Atmosphere station data at in Manas River.

\begin{tabular}{cccccc}
\hline$I D$ & Station & Longitude $(\mathrm{E})$ & Latitude $(\mathrm{N})$ & Elevation $(\mathrm{m})$ & Period of series \\
\hline 51356 & Shihezi & $86^{\circ} 03^{\prime}$ & $44^{\circ} 19^{\prime}$ & 443.7 & $1960.01 .01-2012.12 .31$ \\
51359 & Manas & $86^{\circ} 12^{\prime}$ & $44^{\circ} 19^{\prime}$ & 472.2 & $1960.01 .01-2012.12 .31$ \\
51353 & Mossel Bay & $86^{\circ} 06^{\prime}$ & $45^{\circ} 01^{\prime}$ & 347.2 & $1960.01 .01-2012.12 .31$ \\
51352 & Paotai & $86^{\circ} 15^{\prime}$ & $45^{\circ} 51^{\prime}$ & 337.8 & $1960.01 .01-2012.12 .31$ \\
51357 & Shawan & $86^{\circ} 37^{\prime}$ & $44^{\circ} 20^{\prime}$ & 523.2 & $1960.01 .01-2012.12 .31$ \\
51358 & Wulanwusu & $85^{\circ} 19^{\prime}$ & $44^{\circ} 17^{\prime}$ & 469 & $1960.01 .01-2012.12 .31$ \\
\hline
\end{tabular}

computer program RClimDex, developed and maintained by Zhang Yanwei [17] and Ning Baoying [18]. Software and documentation are available online for downloading (http://cccma.seos.uvic.ca/ETCCDI/software.shtml). Homogeneity assessment and adjustment can be quite complex, and often requires close neighboring stations, detailed station history, and a long time series [19]. Data homogeneity was assessed with the Rhtest software (http://cccma.seos.uvic.ca/ETCCDI/software.shtml), which uses a two-phase regression model to check for multiple step change points that could exit in a time series [20] [21].

After data quality control and homogeneity assessment, RClimDex was used to calculate climate indices from the daily data. Expert Team for Climate Change Detection and Indices (ETCCDI) has been coordinating a suite of 11 precipitation and 16 temperature indices. For percentile indices, a bootstrap procedure has been implemented to ensure that the percentile-based temperature indices do not have artificial jumps at the boundaries of the in-base and out-of-base period [22]. Some of the indices, such as the number of tropical nights, are not relevant to the studied region and were not used, leading to a final selection of 6 temperature indices and 6 precipitation indices (Table 2). They were calculated over the quality controlled data of the stations that passed the homogeneity assessment.

The long-term climatic trends of the eight extreme precipitation indices were studied for the data averaged of the 6 meteorological stations using the linear regressive method. The statistical significance of the trend is evaluated using the rank-based Mann-Kendall trend test [23] [24], which is highly recommended for general use by the World Meteorological Organization [25]. The rank-based MK method is a nonparametric method, commonly used to assess the significance of monotonic trends in hydro-meteorological time series [26]. The MK test has the advantage of not assuming any distribution form for the data and has the power similar to its parametric competitors. The significance of the trend was tested at $>95 \%$ confidence level. 
Table 2. Definitions of six temperature and six precipitation indices used in this paper ${ }^{\mathrm{a}}$.

\begin{tabular}{|c|c|c|c|c|}
\hline & Index & Descriptive name & Definition & Units \\
\hline \multirow{6}{*}{ Temperature } & $\mathrm{TXx}$ & Warmest day & Annual highest TX & ${ }^{\circ} \mathrm{C}$ \\
\hline & $\mathrm{TNn}$ & Coldest day & Annual lowest TN & ${ }^{\circ} \mathrm{C}$ \\
\hline & TN10 & Cold-night frequency & $\begin{array}{c}\text { Percentage of days when TN }<10 \text { th } \\
\text { percentile of 1961-1990 }\end{array}$ & days \\
\hline & TX10 & Cold-day frequency & $\begin{array}{c}\text { Percentage of days when TX }<10 \text { th } \\
\text { percentile of 1961-1990 }\end{array}$ & days \\
\hline & TN90 & Warm-night frequency & $\begin{array}{l}\text { Percentage of days when TN > 90th } \\
\text { percentile of 1961-1990 }\end{array}$ & days \\
\hline & TX90 & Warm-day frequency & $\begin{array}{c}\text { Percentage of days when TX > 90th } \\
\text { percentile of 1961-1990 }\end{array}$ & days \\
\hline \multirow{6}{*}{ Precipitation } & SDII & Simple daily intensity index & Average precipitation on wet days & Mm/day \\
\hline & RX1day & Maximum1-day precipitation & Annual maximum 1-day precipitation & $\mathrm{mm}$ \\
\hline & RX5day & Maximum5-day precipitation & Annual maximum consecutive 5-day precipitation & $\mathrm{mm}$ \\
\hline & CDD & Consecutive dry days & $\begin{array}{l}\text { Maximum number of consecutive dry days } \\
\text { (precipitation }<0.1 \mathrm{~mm} \text { ) }\end{array}$ & days \\
\hline & PRCPTOT & Wet day precipitation & Annual total precipitation from wet days $(\geq 0.1 \mathrm{~mm})$ & $\mathrm{mm}$ \\
\hline & R95p & Very wet day precipitation & $\begin{array}{l}\text { Annual total precipitation when } R R>95 \text { th } \\
\text { percentile of } 1961-1990 \text { daily precipitation }\end{array}$ & $\mathrm{mm}$ \\
\hline
\end{tabular}

Notes: all the indices are calculated by RCLimDEX. Abbreviations are as follows: TX, daily maximum temperature; TN, daily minimum temperature; TG, daily mean temperature; $R R$, daily precipitation. A wet day is defined when $R R \geq 0.1 \mathrm{~mm}$, and a dry day is defined when $\mathrm{RR}<0.1 \mathrm{~mm}$. Indices are included for completeness but are not analyzed further in this article.

\section{Results and Analyses}

\subsection{Trend Changes for Extreme Climatic Events in the Manas River Basin}

\subsubsection{Interannual Variation of Extreme Temperature}

Figure 2 shows the average year-by-year change and the 5-year moving average for the highest and lowest extreme temperatures during 1960-2012 in the Manas River basin. Both highest and lowest temperatures exhibited a rising trend, with the highest temperature rising $0.22^{\circ} \mathrm{C} / 10 \mathrm{a}(p<0.05)$ and with the lowest temperature rising $0.24^{\circ} \mathrm{C} / 10 \mathrm{a}(p<0.01)$. We can see that the increase is greater for the minimum than for the maximum temperature.

Figure 3 depicts change conditions for cold-night frequency (TN10) and warm-night frequency (TN90) indices in the Manas River basin. The indices for cold-night and warm-night frequency both show rising trends, but these trends were not significant.

Figure 4(a) illustrates the cold-day frequency (TX10P) in the Manas River basin, showing a trend that declines $1.2 \mathrm{~d} / 10 \mathrm{a}$, but the trend was not significant. However, the warm-day frequency (TX90P) shows a trend rising $0.77 \mathrm{~d} / 10 \mathrm{a}$, which was significant at the 0.05 level.

\subsubsection{The Interannual Variation in Extreme Precipitation Events}

In Figure 5, the occurrence frequency for extreme precipitation indices RX1 day, RX5day, SDII, R95, and PRCPTOT during 1961-2010 generally shows a rising trend (Figures 4(a)-(e)), indicating that extreme precipitation events increased during this period. Continuous drought days (CDD) declined (Figure 5(f)), suggesting that drought in the Manas River basin eased during the 50-year period studied and conditions are now more humid. From the 5-year moving-average curve for 50 years (Figures 5(a)-(e)), we can see that occurrence frequency has possible interannual features, with the appearance of a negative anomaly prior to mid-1980 that changed to a positive anomaly from 1980 to 2010, with a trend toward increasing frequency. Yet Figure 5(f) shows a negative anomaly from 1999 to 2010, illustrating that the occurrence frequency generally decreased during the 50-year period, according to the 5-year moving-average. Extreme precipitation indices show a potential regime shift starting from the middle of 1980s. 


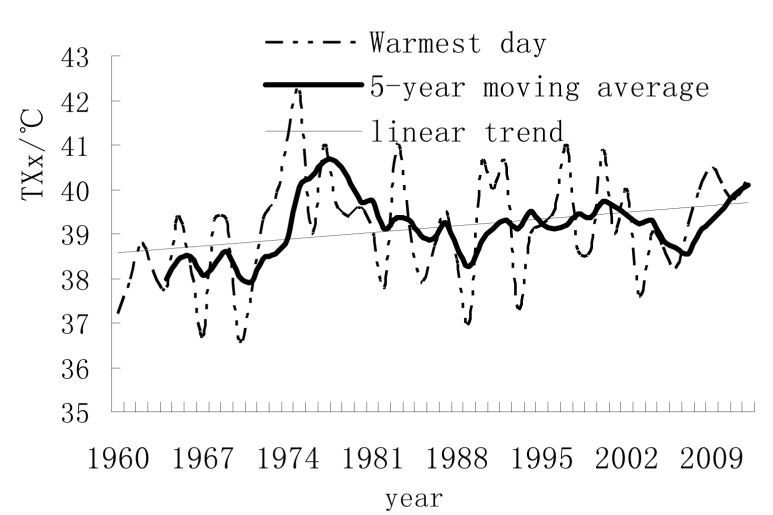

(a)

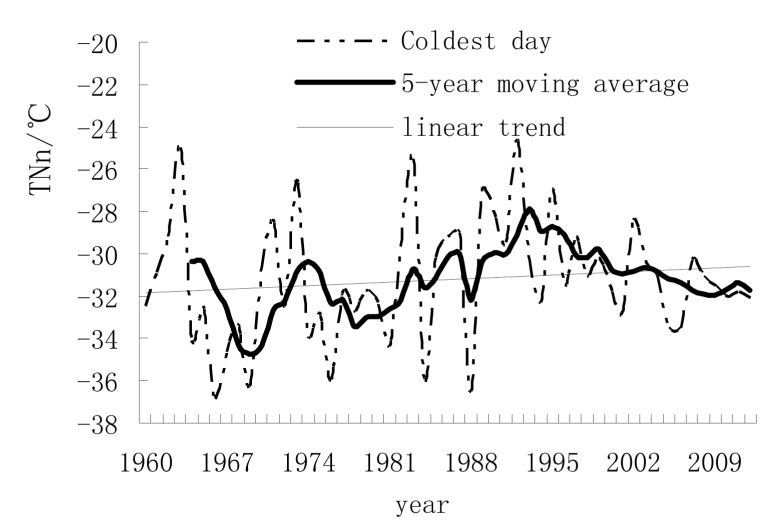

(b)

Figure 2. Interannual variation in temperature extremes in the Manas River basin, China, during 1960-2012 (TXx and TNn).

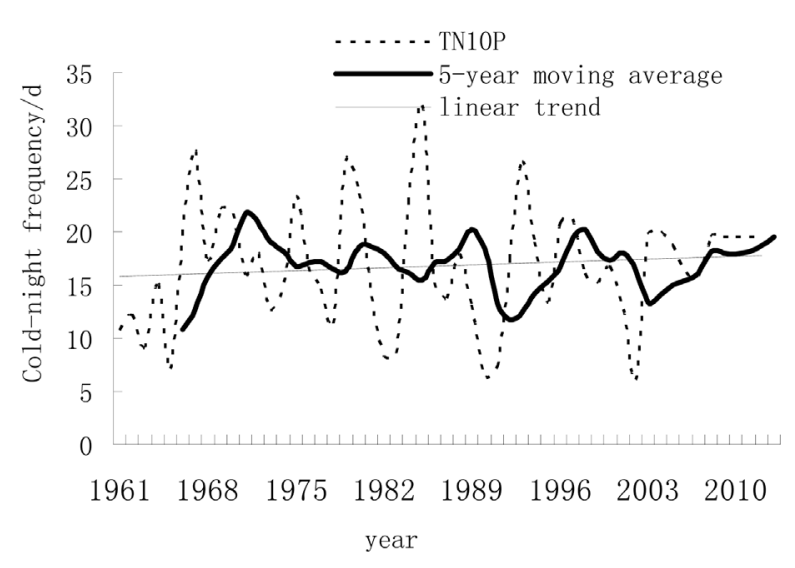

(a)

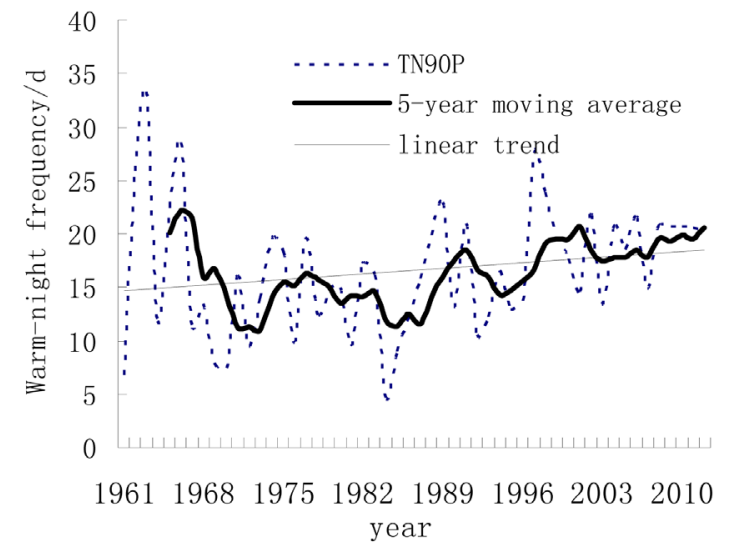

(b)

Figure 3. Interannual variation in temperature extremes in Manas River basin, China, during 1960-2012 (TN10P and TN90P).

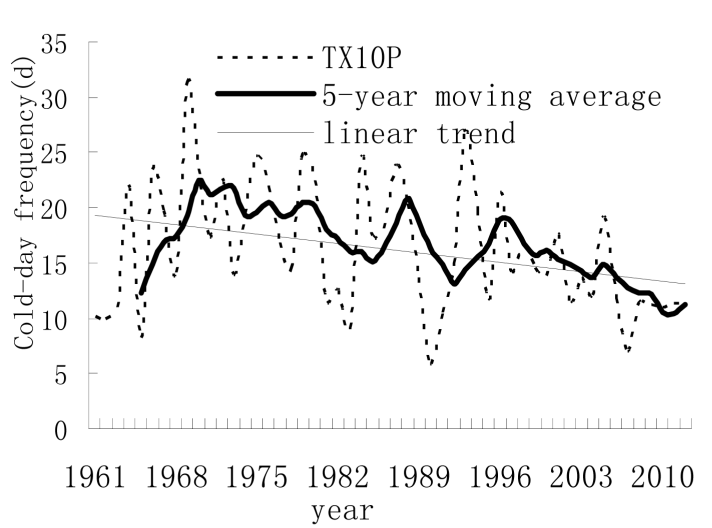

(a)

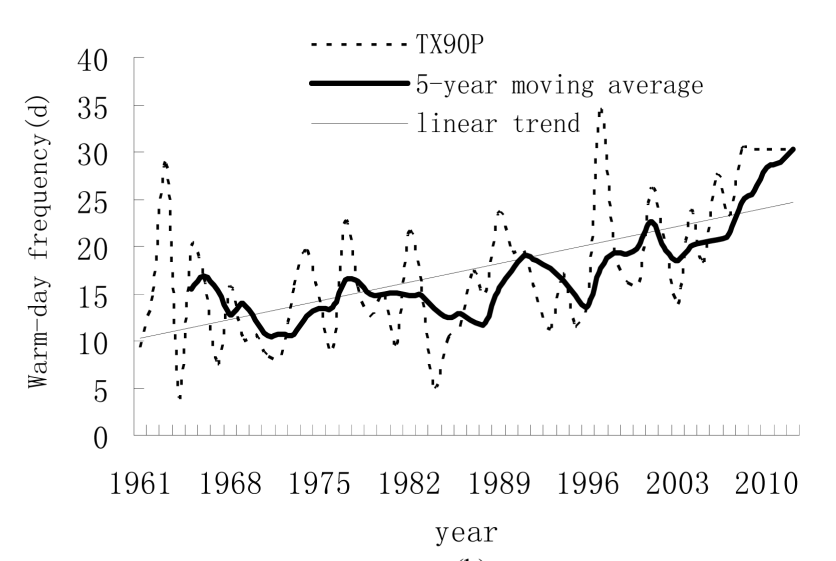

(b)

Figure 4. Interannual variation of temperature extremes in Manas River basin, China, during 1960-2012 (TX10P and TX90P).

3.1.3. Seasonal Variation Analysis on Extreme Temperature and Precipitation

From Figure 6(a) and Table 3 shows that in past 52 years, the extreme maximum temperature, in Manas Rivers, 


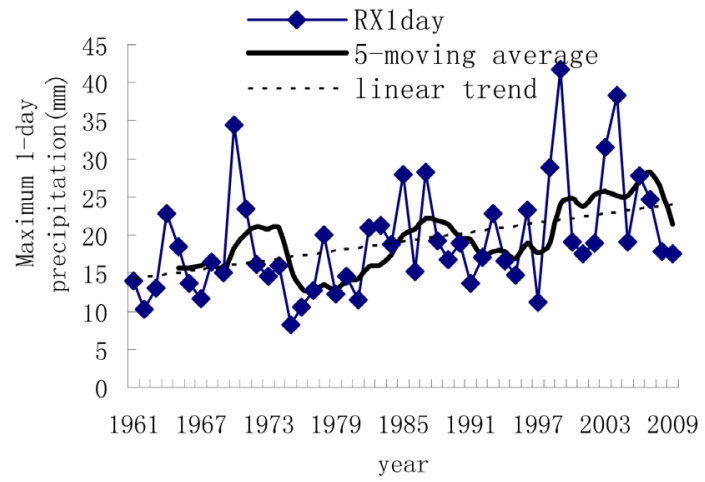

(a)

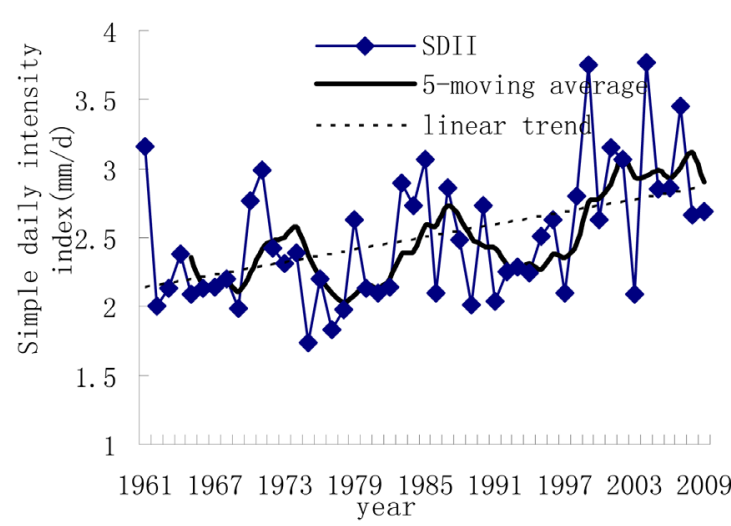

(c)

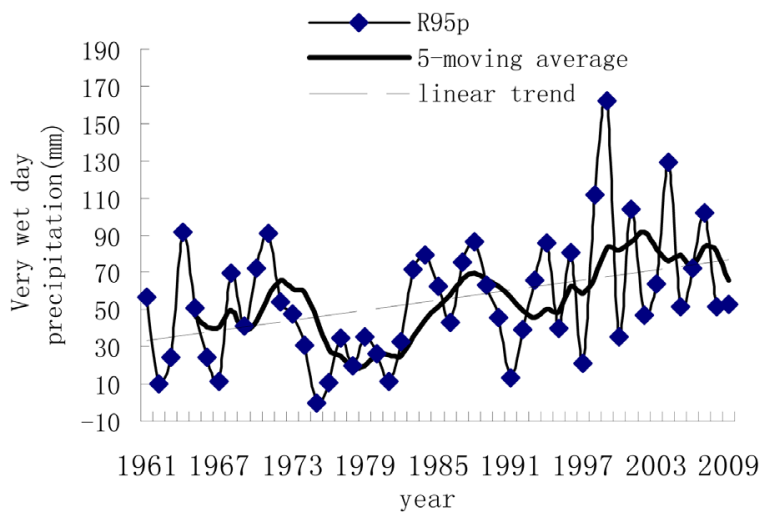

(e)

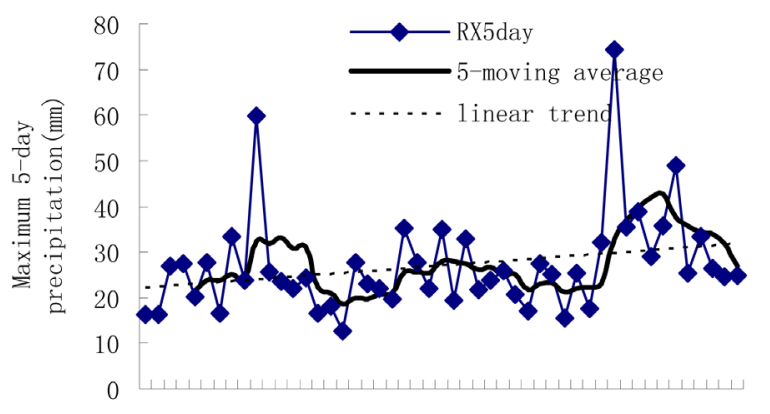

196119671973197919851991199720032009

year

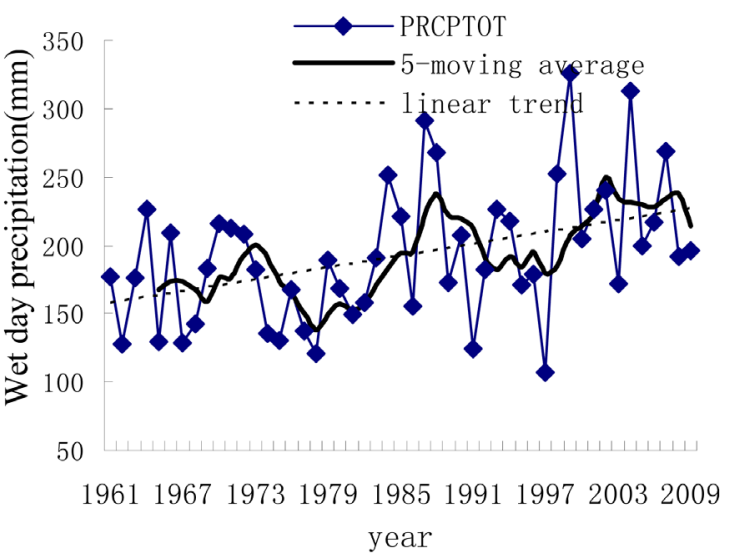

(d)

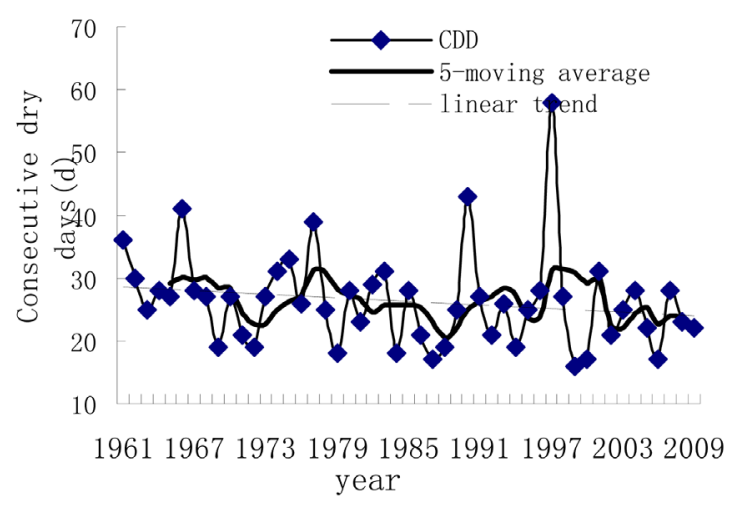

(f)

Figure 5. Interannual variation in extreme precipitation indices (a) RX1day, (b) RX5day, (c) SDII, (d) R95, (e) PRCPTOT, and (f) CDD.

reveal a rising trend in Spring, Summer and Autumn reveal a decline trend in Winter during 1961-2012. the maximum climbing speed is $0.63^{\circ} \mathrm{C} / 10 \mathrm{a}$ in Autumn, the second rank is in Summer, and the minimum climbing speed is $0.16^{\circ} \mathrm{C} / 10 \mathrm{a}$. The coefficient of association between Spring, Summer, Autumn as well as Winter and year is $0.283,0.192,0.388$ and -0.132 separately. Among in which, the coefficient of association between in Spring, Autumn and year had passed the significance level test of $\alpha=0.05$ and $\alpha=0.01$ respectively. From Figure 6(b) and Table 4 shows that in past 52 years, the extreme minimum temperature, in Manas Rivers, reveal a rising trend, in Spring is most obviously, following is Summer and Autumn. The minimum climbing speed is in Winter. The coefficient of association between Spring, Summer, Autumn as well as Winter and year is 0.285 , 

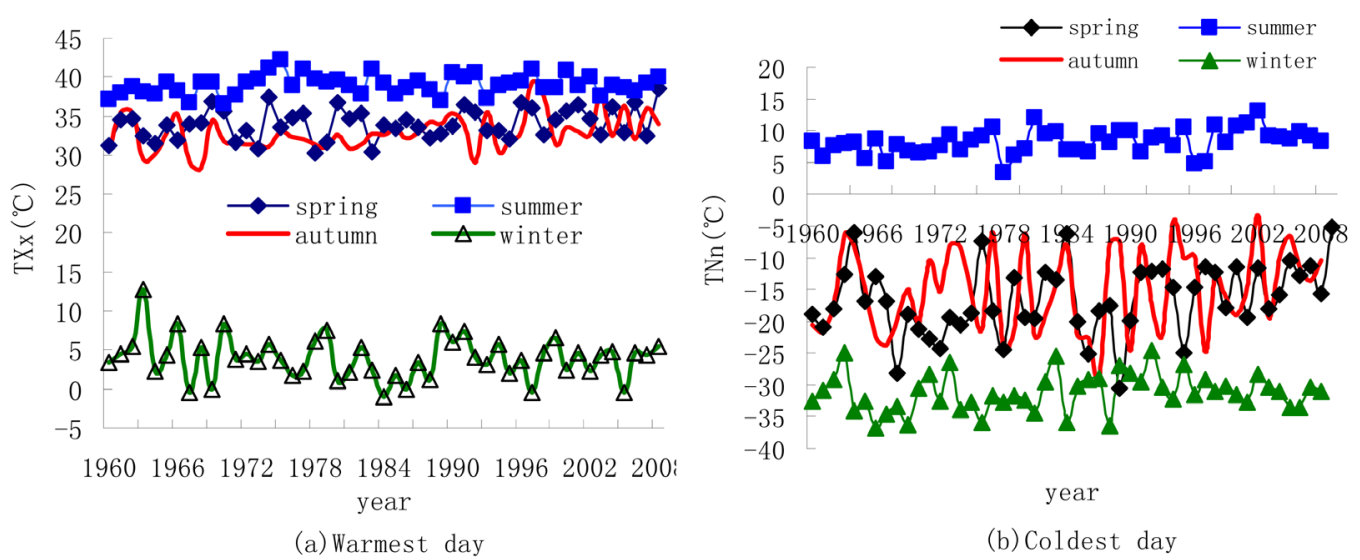

(b) Coldest day

Figure 6. The variation trend of extreme maximum temperature and minimum temperature in four seasons in Manas Rivers Basin from 1961 to 2012 (a) Warmest day; (b) Coldest day.

Table 3. Statistical result for extreme maximum temperature and minimum temperature in four seasons.

\begin{tabular}{ccccc}
\hline \multirow{2}{*}{ Season } & \multicolumn{2}{c}{$T X x$ (Warmest day) } & \multicolumn{2}{c}{$T$ TNn (Coldest day) } \\
\cline { 2 - 5 } & $\begin{array}{c}\text { Climate tendency rate } \\
\left({ }^{\circ} \mathrm{C} / 10 \mathrm{a}\right)\end{array}$ & $\begin{array}{c}\text { Coefficient of association } \\
\text { with year }\end{array}$ & $\begin{array}{c}\text { Climate tendency rate } \\
\left({ }^{\circ} \mathrm{C} / 10 \mathrm{a}\right)\end{array}$ & $\begin{array}{c}\text { Coefficient of association } \\
\text { with year }\end{array}$ \\
\hline Spring & 0.16 & $0.283^{*}$ & 1.1 & $0.285^{*}$ \\
Summer & 0.39 & 0.192 & 0.53 & $0.387^{* *}$ \\
Autumn & 0.63 & $0.388^{* *}$ & 0.93 & 0.199 \\
Winter & -0.25 & -0.132 & 0.37 & 0.177 \\
\hline
\end{tabular}

Note: ${ }^{*},{ }^{* *}$ denote that the correlation is significant at the 0.05 and 0.01 levels, respectively.

Table 4. Basic moments and tests of annual maximum runoff at Kensiwate stations.

\begin{tabular}{cccccccc}
\hline Station name & Mean value & $\begin{array}{c}\text { Standard } \\
\text { deviation }\end{array}$ & $\begin{array}{c}\text { Coefficient of } \\
\text { skew }\end{array}$ & $\begin{array}{c}\text { Coefficient of } \\
\text { kurtosis }\end{array}$ & Run test & Tendency test & $M-K$ test \\
\hline Kensiwate & 366.62 & 168.12 & 2.325 & 6.962 & 0 & 0 & 0.059
\end{tabular}

Note: Accept null hypothesis under the confidence level of $95 \%$, reject null hypothesis under the confidence level of $95 \%$, the null hypothesis is sequence with independent identically distributed.

0.387, 0.199 and 0.177 separately. Among in which, the coefficient of association between in Spring, Summer and year had passed the significance level test of $\alpha=0.05$ and $\alpha=0.01$ respectively. Illustrate that extreme maximum temperature and extreme temperature in Spring, Summer, Autumn exist consistent temperature increasing trends.

The conclusions can be made, through the four seasons data series of statistical analysis for data from daily maximum precipitation (RX1day) and 5 days maximum precipitation (RX5day) in Manas Rivers during 19612012, in past 52 years, the four seasons precipitation of RX1day, RX5day all show increasing trend (see Figure 7). The maximum climbing speed for RX1day and RX5day both are in Summer, the value is $4.95 \mathrm{~mm} / 10 \mathrm{a}$ and $3.52 \mathrm{~mm} / 10$ a respectively, the minimum speed both are in Spring, the value is $1.38 \mathrm{~mm} / 10 \mathrm{a}$ and $1.54 \mathrm{~mm} / 10 \mathrm{a}$, which all had passed the significance level test with $\alpha=0.01$, demonstrate that extreme precipitation is mainly in Summer.

\subsection{The Effect of Extreme Climatic Events on Extreme Runoff in Manas Rivers Basin during 1961-2012}

\subsubsection{Evolution Tendency Analysis for Extreme Runoff in the Manas River}

Using annual runoff data from the Kensiwate hydrologic stations in the Manas River basin, the mean value, 


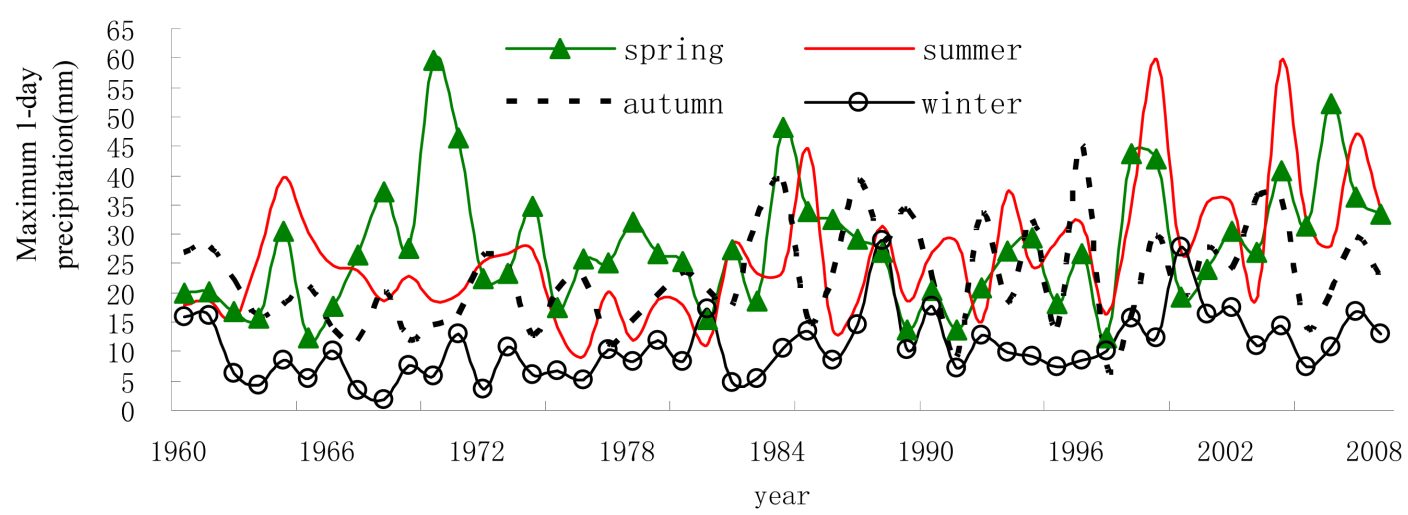

(a) RX1day

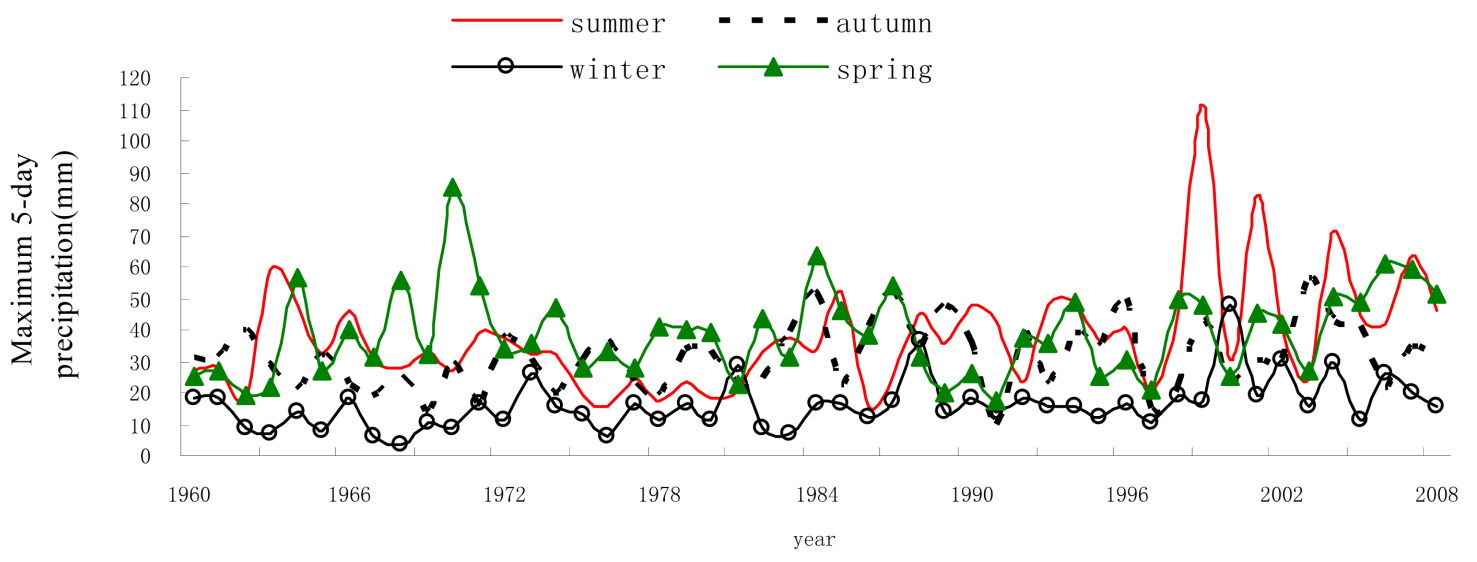

(b) RX5day

Figure 7. Variation trend of four seasons extreme precipitation volume in Manas Rivers Basin from 1961 to 2012. (a) RX1day; (b) RX5day.

standard deviation, coefficient of dispersion, coefficient of skew, and coefficient of kurtosis were calculated, and then the trend test and Mann-Kendall (M-K) test were applied to analyze the change in maximum runoff volume.

The maximum daily runoff volume at the Kensiwate stations is displayed for 28 July 1966, 27 July 1980, and 2 August 1999 during 1960-2010. Results of the M-K test of the increasing trend for the maximum daily runoff was not significant $(|\mathrm{Z}|=1.417<1.96, p>0.05)$. From exploratory analysis of the data, we conclude that the maximum daily runoff volume in the Manas River was inflated by runoff in the July-August 1990 flood season.

From Figure 8 Variation of the monthly mean runoff in Manas River Kensiwate stations during 1960-2012, we can see that the annual distribution in Manas River is quite uneven, which the minimum flow is in February, the flow began to gradually rise till on March to May, the flow increased sharply till on June, so the flow reach to peak till on July, then began to decrease gradually on August, at the early of October, the flow began to decrease obviously, till December, the extreme minimum value appeared again.

\subsubsection{Extreme Runoff Response to Extreme Climatic Change}

1) Sudden flood response to runoff change

The annual runoff distribution in the Manas River showed great variation; the $\mathrm{C}_{\mathrm{V}}$ value was 0.45 , and the volume at flood season (June-August) accounted for 83.7\% of annual runoff volume. Manas River runoff was closely related to sudden glacial outbursts and to peak discharge, both showing correlations of $0.658(p<0.05)$ When the increase in annual runoff, the maximum peak discharge also increased the peak flow, the change trend of the two remained the same (Figure 9). 

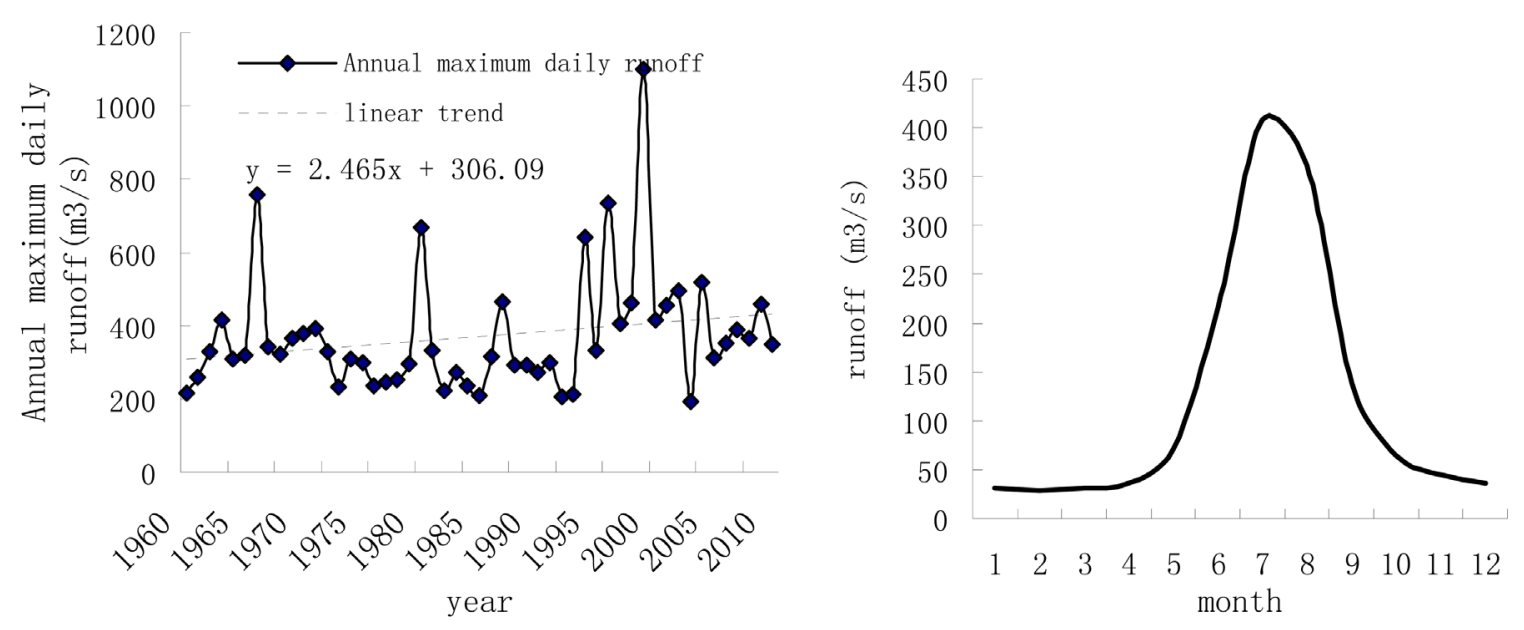

Figure 8. Variation of the annual maximum runoff and monthly mean runoff at the Kensiwate stations during 1960-2010.

2) The occurrence frequency of sudden floods as a response to climatic variation.

Maximum peak discharge data from 1957-2010 recorded at hydrologic stations of the Manas River were selected as a series of actual flood measurements, and we applied Pearson III methodology to determine the relationship between flood frequency (Figure 10) and the peak discharge (Table 5). From Figure 8 and Table 5, we can see that the 500-year-flood peak discharge is $1116 \mathrm{~m}^{3} / \mathrm{s}$, and the 100 -year flood is $906 \mathrm{~m}^{3} / \mathrm{s}$, which are very important guidelines for flood design, hydraulic engineering, flood control projects, and urban construction.

Regard peak discharge, $486 \mathrm{~m}^{3} / \mathrm{s}$ occurring once in 5 years as a parameter so that the count of flood occurrence frequency in the Manas River during 1960-2010 (Figure 11).

In the Manas River basin, the extreme temperature began to rise in the 1980s, culminating in the 1990s. Along with the temperature rise, glacial ablation accelerated, and extreme precipitation increased. As a result, flood occurrence frequency during 1990s accounted for $42.9 \%$ of the total flood frequency since the 1960s. Meanwhile, using SPSS 17.0, we analyzed extreme temperature, precipitation, and extreme runoff, and the correlation coefficients of maximum peak discharge with monthly maximum precipitation, simple precipitation intensity, annual maximum runoff volume, and summer high temperature of $0.483,0.562,0.804$, and 0.756 , respectively (all $p<0.01$ ). These results indicate that floods have been increasing in the Manas River basin mainly because of increasing precipitation and increased ice- and snowmelt, caused by increasing high temperatures in summer. Together, these changes result in increased river inflow and variation in peak discharge.

\section{Conclusions}

This paper adopts 6 extreme temperature indices and 6 precipitation indices so that study change features on extreme climate events and effects on extreme runoff volume change in Manas River in past 52 years. The mainly conclusions as following:

1) In the past 50 years, extreme warming events (annual extreme maximum temperature, warm-day index, and warm-night index) all appear to be significantly rising tendency $(p<0.05)$, in which the trend rising on extreme maximum temperature and warm-day index is significant, and the range of rising is $0.22^{\circ} \mathrm{C} / 10 \mathrm{a}$ and 0.77 $\mathrm{d} / 10 \mathrm{a}$, respectively $(p<0.05)$. However, the rising trend for the warm-night index is not significant. With respect to extreme cold events (annual extreme minimum temperature, cold-day index, and cold-night index), cold-day index shows a declined trend, and the range of decreasing is $1.2 \mathrm{~d} / / 10 \mathrm{a}$, which fails to pass the significance level test with 0.05 . But annual extreme minimum temperature and cold-day index show a rising trend, whose range of rising is $0.24^{\circ} \mathrm{C} / 10 \mathrm{a}, 0.38 \mathrm{~d} / / 10$ a separately and all have passed significance level test with 0.05 .

2) Range of variation on extreme cold index and warm index, nighttime index as well as daytime index reveals an obvious feature with asymmetry; the change feature demonstrates that the range of variation on cold index is more than that of warm index, and the nighttime index is more than daytime index.

3) In the past 50 years, each index on extreme precipitation events has a significant annual intergeneration feature; generally, it shows a rising trend (apart from CDD). The period for extreme precipitation is inclined to be less before middle of 1990; after this period, the period is inclined to be more. Among them, CDD is inclined 


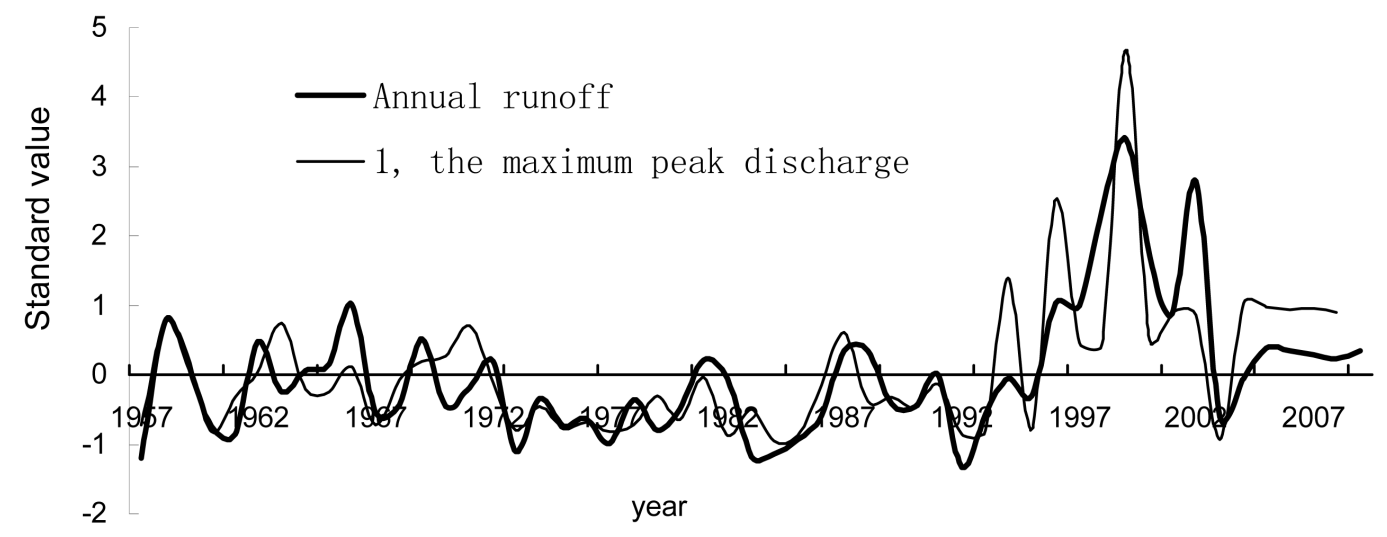

Figure 9. Relationship between Manas River valley glacial outburst flood peak discharge and runoff amounts.

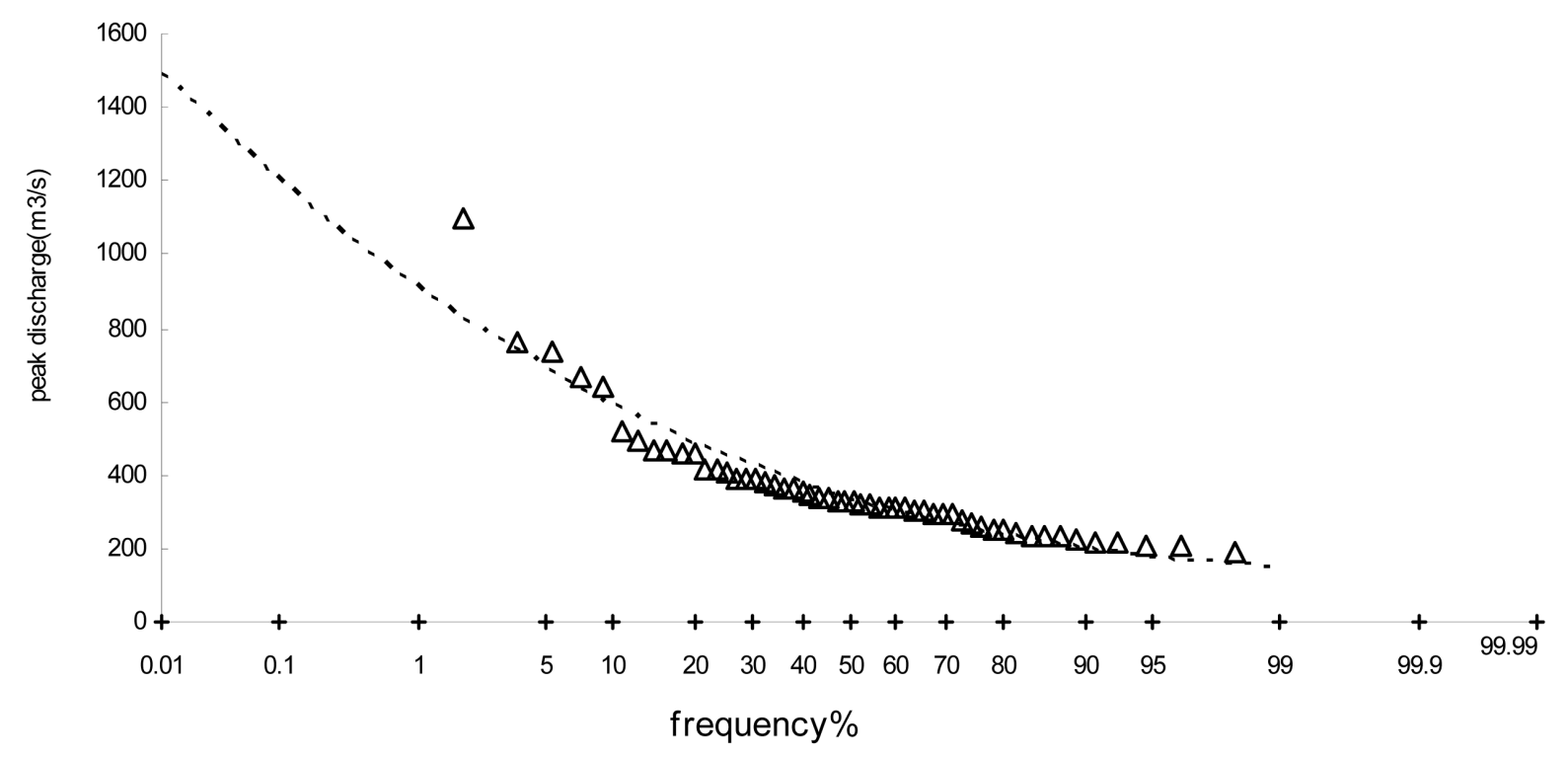

Figure 10. Actual measured flood frequency curve graph during 1957-2010 in the Manas River ( $\Delta$ depicts actual measured flood).

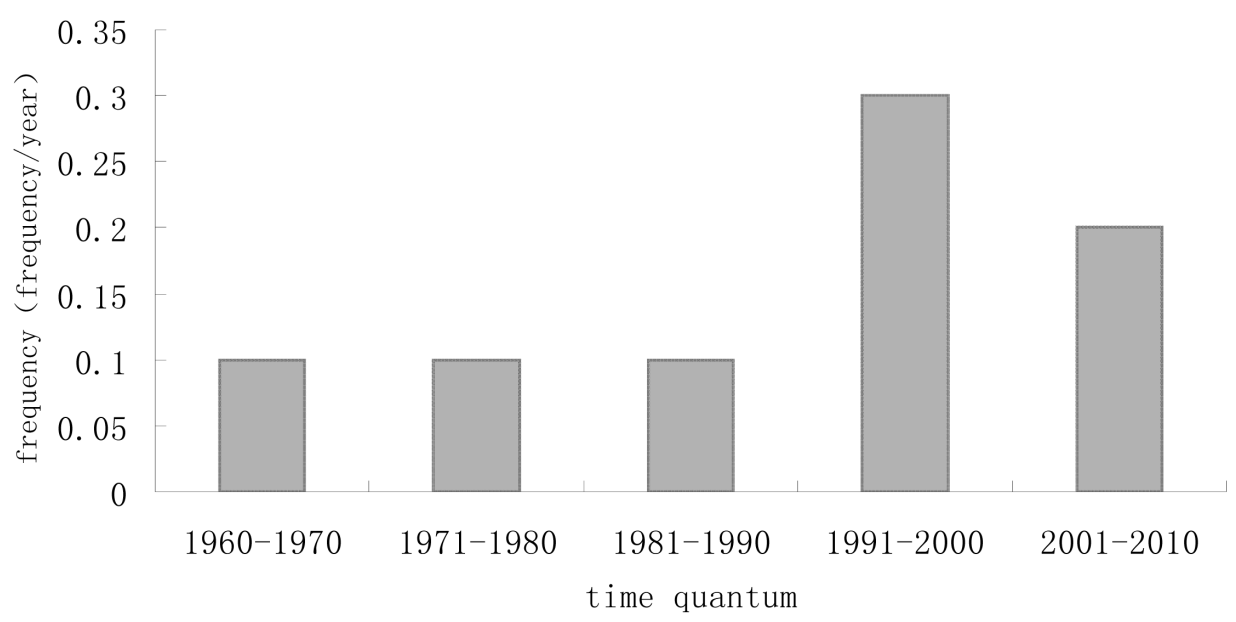

Figure 11. The average frequency of flood in the Manas River basin during 1960-2010. 
Table 5. Sudden flood frequency and corresponding peak discharge in the Manas River.

\begin{tabular}{cccccccccc}
\hline Frequency P\% & 0.1 & 0.2 & 0.5 & 1 & 2 & 5 & 10 & 20 & 50 \\
\hline $\begin{array}{c}\text { recurrence } \\
\text { interval N year }\end{array}$ & 1000 & 500 & 200 & 100 & 50 & 20 & 10 & 5 & 2 \\
$\mathrm{Qp} / \mathrm{m}^{3} \cdot \mathrm{s}^{-1}$ & 1201 & 1116 & 995 & 906 & 814 & 689 & 589 & 486 & 332 \\
\hline
\end{tabular}

to be large before middle of 1920; however, after this period, the period is inclined to be small, indicating that the drought has been relieved in Manas Rivers after middle of 1990.

4) The extreme maximum temperature rising in Manas Rivers is mainly in Autumn and Summer, the minimum temperature rising is mainly in Spring and Autumn, and the extreme precipitation increasing is mainly in Summer. The flood of occurred frequency in Manas Rivers was increasing in Summer of 1990, probably due to extreme high temperature as a result of increasing ice and snow of melt water. The inflow of river is increasing, and precipitation is inclined to be more, indicating that occurrence and its changes on extreme climate events greatly affect drought and flood disasters as well as water resources management in Manas Rivers.

\section{Acknowledgements}

This study is jointly financed by the Xinjiang Uygur Autonomous Region Key Laboratory of "Xinjiang laboratory of Lake Environments and Resources in Arid Zone” (XJDX0909-2012-12), the National Natural Science Foundation Project of China (41001020), and the Shihezi University team innovation project (2011ZRKXTD0504). The authors gratefully acknowledge funding for this research and would like to express their sincere thanks to Zhang Yan Wei and Wang Xia Qin for the help with data.

\section{References}

[1] Lin, E.D., Xu, Y.L., Jiang, J.H., et al. (2007) Climatic Change National Assessment Report (II), Influence and Adpt of Climatic Change. Climatic Change Research Progress, 2, 51-56.

[2] Trenberth, K.E., et al. (2007) Observations: Atmospheric Surface and Climate Change//Climate Change 2007: The Physical Science Basis. Cambridge University Press, Cambridge, 235-336.

[3] Du, H., Xia, J., Zeng, S.D., et.al. (2012) Spatio-Temporal Variation Rules and Statistic Simulation of Extreme Runoff in Huai River Basin. Geography Journal, 67, 398-409.

[4] Houghton, J.T., Ding, Y., Griggs, D.J., Noguer, M., van der Linden, P.J., Dai, X., Maskell, K. and Johnson, C.A. (2001) Climate Change 2001. The Scientific Basis. Cambridge University Press, Cambridge.

[5] Solomon, S., Qin, D., Manninget, M., et al. (2007) Climate Change 2007: The Physical Science Basis. Contribution of Working Group I to the Fourth Assessment Report of the Intergovernmental Panel on Climate Change. Cambridge University Press, Cambridge.

[6] Jiang, F.-Q., Hu, R.-J., Zhang, Y.-W., et al. (2013) Trends of Precipitation Extremes during 1960-2008 in Xinjiang, the Northwest China. Theoretical and Applied Climatology, 111, 133-148. http://dx.doi.org/10.1007/s00704-012-0657-3

[7] Kunkel, K.E., Andsager, K., et al. (1999) Long-Term Trends in Extreme Precipitation Events over the Conterminous United States and Canada. Journal of Climate, 12, 2515-2527. http://dx.doi.org/10.1175/1520-0442(1999)012<2515:LTTIEP>2.0.CO;2

[8] Manton, M J., Della-Marta, P.M., Haylock, M.R., et al. (2001) Trends in Extreme Daily Rainfall and Temperature in Southeast Asia and the South Pacific: 1961-1998. International Journal of Climatology, 21, 269-284. http://dx.doi.org/10.1002/joc.610

[9] Groisman, P., Karl, T., Easterling, D., et al. (1999) Changes in the Probability of Extreme Precipitation: Important Indicators of Climate Change. Climatic Change, 42, 243-283. http://dx.doi.org/10.1023/A:1005432803188

[10] Karl, T.R., Knight, R.W. and Plummer, N. (1995) Trends in High-Frequency Climate Variability in the Twentieth Century. Nature, 377, 217-220. http://dx.doi.org/10.1038/377217a0

[11] Rajeevan, M., Bhate, J. and Jaswal A.K. (2008) Analysis of Variability and Trends of Extreme Rainfall Events over India Using 104 Years of Gridded Daily Rainfall Data. Geophysical Research Letters, 35, L18707.

[12] Zhai, P.M., Ren, F.M. and Zhang, Q. (1999) Detection of Trends in China’s Precipitation Extremes. Acta Meterorologica Sinica, 57, 208-216.

[13] Ding, Y.H., Ren, Y.G., Shi, G.Y., et al. (2006) National Assessment Report of Climate Change (I): Climate Change in 
China and Its Future Trend. Advances in Climate Change Research, 2, 3-8.

[14] Jiang, Z.H., Ding, Y.G. and Chen, W.L. (2007) Projection of Precipitation Extremes for the 21st Century over China. Advances in Climate Change Research, 3, 202-207.

[15] Su, B.D., Jiang, T. and Dong, W.J. (2008) Probabilistic Characteristics of Precipitation Extremes over the Yangtze River Basin. Scientia Meteorologica Sinica, 28, 625-629.

[16] Yang, L.M. (2003) Climate Change of Extreme Precipitation in Xinjiang. Acta Geographica Sinica, 58, 577-583.

[17] Zhang, Y.W., Wei, W.S. and Jiang, F.Q. (2012) Trends of Extreme Precipitation Events over Xinjiang during 19612008. Journal of Mountain Science, 30, 417-424.

[18] Ning, B.Y., Yang, X.M. and Chang, L. (2012) Changes of Temperature and Precipitation Extremes in Hengduan Mountains, Qinghai-Tibet Plateau in 1961-2008. Chinese Geographical Science, 22, 422-436. http://dx.doi.org/10.1007/s11769-012-0549-6

[19] Vincent, L.A., Peterson, T.C., Barros, V.R., et al. (2005) Observed Trends in Indices of Daily Temperature Extremes in South America 1960-2000. Journal of Climate, 18, 5011-5023. http://dx.doi.org/10.1175/JCLI3589.1

[20] Wang, Y.Q. and Zhou, L. (2005) Observed Trends in Extreme Precipitation Events in China during 1961-2001 and the Associated Changes in Large-Scale Circulation. Geophysical Research Letters, 32, L09707. http://dx.doi.org/10.1029/2005GL023769

[21] Zhang, X.B., Aguilar, E., Sensoy, S., et al. (2005) Trends in Middle East Climate Extreme Indices from 1950 to 2003. Journal of Geophysical Research, 110, D22104. http://dx.doi.org/10.1029/2005jd006181

[22] Zhang, X.L., Hegerl, G., Zwiers, F.W. and Kenyon, J. (2005) Avoiding Inhomogeneities in Percentile-Based Indices of Temperature Extremes. Journal of Climate, 18, 1641-1651.

[23] Mann, H.B. (1945) Nonparametric Tests against Trend. Econometrica, 13, 245-259. http://dx.doi.org/10.2307/1907187

[24] Sneyers, R. (1990) On the Statistical Analysis of Series of Observations. Vol. 415, WMO, World Meteorological Organization, Geneva, 192.

[25] Serrano, V.L., Mateos, V.L. and García, J.A. (1999) Trend Analysis of Monthly Precipitation over the Iberian Peninsula for the Period 1921-1995. Physics and Chemistry of the Earth, Part B: Hydrology, Oceans and Atmosphere, 24, 85-90. http://dx.doi.org/10.1016/S1464-1909(98)00016-1

[26] Yue, S. and Pilon, P. (2004) A Comparison of the Power of the t Test, Mann-Kendall and Bootstrap for Trend Detection. Hydrological Sciences Journal, 49, 21-37. http://dx.doi.org/10.1623/hysj.49.1.21.53996 